\title{
The Nature and Classification of Traditional Religious Songs in Irish
}

\author{
WITH A SURVEY OF PRINTED AND ORAL SOURCES
}

\author{
NórRín Ni RIAIN
}

\section{INTRODUCTION}

In the earlier sources of ecclesiastical literature, the scanty details of early Irish chant are conveyed primarily through the lives of the saints. From these details it is difficult to discuss the precise musical nature of the chant. However, it is possible to state that church chant was an integral part of monastic life from the time of St Patrick. The type of chant in use at this time would appear to have been a form of Gallican chant which gave way to the more ornate, intricate Roman chant in the twelfth century. With the official establishment of the Anglo-Roman liturgy in 1172, the old Irish liturgy was suppressed.

From a study of the texts of two seventh-century hymns, Aloys Fleischmann discusses their possible musical form. The first hymn, Sen Dé, written probably in the late seventh century, is irregular from the point of view of metre, rhyme and stress.

The second seventh-century hymn, Celebra Juda by St Cummain,

shows a typically Irish structure with end rhymes, and an interesting feature is the alleluia refrain sung after every two lines, suggesting a form of litany with a recurring melodic formula. The repetition of the alleluia after each verse is a device also found in two hymns of the seventh-century Bangor Antiphonary.

The Antiphonary of Bangor -an antiphonary written between 680 and 691 at the monastery of Bangor, Co. Down-contains the only remnants of that era of chant prior to the Romanizing movement. Of the twelve hymns in this antiphonary, eight appear to be peculiarly Irish since they do not appear in any other source. The hymn Sancti Venite - "probably composed in the 6th century" - is one of these to be discussed in this paper.

The Liber Hymnorum is a twelfth-century literary source of old Irish and Hiberno-Latin hymns. It also refers to the hymn Sancte Venite with a note on its history in the Preface, and two other hymns in this collection refer specifically to psalmody and hymn-singing.

It is evident that this early chant was accompanied by a small eight-stringed harp which was hung from the girdle. The latest reference to this practice was made in the twelfth century by Giraldus Cambrensis, who describes the clerics devoutly playing on their harps.

In the later sources of ecclesiastical literature, a closer insight into the musical nature of this early chant is given through the musicoliturgical MSS, the earliest being The Drummond Missal of the eleventh century. This sole instance of the earliest type of inflection marks and neumes,

...show $[s]$ little trace of an indigenous mode of music-writing, being to a great extent reflections of the mode used contemporaneously in England or in France as the case might be.

Later examples of neumes are, on the whole, confined to the-extant liturgical books of the various orders which carne to settle in Ireland from the twelfth century onwards.

The fourteenth-century Red Book of Ossory contains, among various statutes and constitutions, fifteen pages of sixty Latin religious verses called Cantilenae. These verses, in honour of the Holy Spirit, the Virgin Mary and Christ, were written by Bishop Ledrede who came from London to Ossory in 1317. Some eight of these bear a popular tune title to which they were sung. Six of the titles are 
English folk tunes which were obviously well known at the time, the two remaining titles are French.

That the streets of Kilkenny were often enlivened by songs that were too worldly for Bishop Ledrede's pious ears "cantilenis teatralibus turpibus et secularibus" is plain from the fact that the bishop went to the trouble of composing some sixty cantilenae in Latin, which were of a more edifying character but could be sung to tunes which less edifying English and French words had made popular in the city.

The practice of setting religious texts to popular tunes of the people was repeated intermittently from the fourteenth century onwards. Three centuries later, in 1684, Bishop Luke Wadding wrote English religious texts to be sung to English and Irish folk tunes and printed these texts in a book entitled A Pious Garland. It is interesting to note that it was not the intention of Bishop Wadding to integrate his songs into church worship and that his prime motivation for composition was "for the Solace of his Friends and Neighbours in their affliction".

In an editorial note to the reader inserted in the 1728 edition of A Pious Garland, the editor reinforces what he feels were the intentions of the author and here no mention is made of any church connection:

...I pray practise these following little SONGS and recommend them to others, to some they will be comfortable pleasing, tho not to all, firmly hoping that the Number of those that will profit by it will be many.

Fr. William Devereux (1698-1771) during his pastorate of Drinagh compiled a collection of carols, some of which he wrote himself and some which he took from Bishop Wadding's collection. He called his collection the New Garland to distinguish it from the earlier collection.

The carols had a wide appeal; manuscript copies of the New Garland were multiplied and the songs were introduced to the neighbouring parishes of Ballymore, Moyglass, Lady's Island, Tacumshin, Kilmore and Rathangan.

The singing of these carols today is confined to the parish of Kilmore in south-east Wexford. Six men, all related and under the-leadership of Jack Devereux, come together during the Sundays and holydays of the twelve days of Christmas and sing a limited selection from the thirteen carols which have survived in Fr. Devereux's New Garland.

The seventeenth century's recurring waves of rebellion and revolution had gradually eroded the political and economic position of the Catholic people. Thus, the Penal code was enforced shortly after the Treaty of Limerick and reached its climax during the reign of Queen Anne. This system of laws was not only aimed against the Roman Catholics but also against all Protestant non-conformists. However, two-thirds of the population were Catholic at this time.

These stringent laws and the inability of the clergy to provide a means of church worship led to appalling conditions in the few instances where this worship took place:

There was nothing in existence for the Catholics for the worship of God, except the mere altar covered with a little open roof to protect the priest from rain, which it was incapable of doing. The altar was about two feet in depth and the open shed which covered it not more than three... There was always a little plot of green sward allowed to be annexed to the altar on which the congregation could kneel... during the winter months the worship of God was in one sense a very trying ceremony.

The religious expression of the Irish Catholic was not however stifled but gave rise to an entirely individual approach where innate spirituality became fully integrated into daily life. Irish prayers abound for the various mundane activities such as greeting one another, lighting the fire, making the bread or smoking a pipe. So too, religious expression through song became for the most part non-liturgical and shared a similar social situation and performance medium to those of the secular song.

Therefore, given the various strands of early religious music in Ireland, two factors are noteworthy-firstly, 
the lack of any notated examples of this music before the nineteenth century, and secondly, the obvious use of oral transmission as the means of communicating these pieces from one generation to the next.

From the nineteenth century onwards, various collectors have notated religious songs, and along with this a body of religious songs survived orally into the twentieth century virtually unnoticed. In identifying this repertoire it is possible to discount current popular belief in the non-existence of a distinctive Irish religious song type. Furthermore, an examination of these songs from the point of view of tunes and texts show many of them to be among the oldest surviving music in the living tradition.

\section{THE SOURCES OF TRADITIONAL RELIGIOUS SONG IN IRISH}

The basic criterion in establishing the authenticity of a traditional religious song is that text and tune can be seen to have been traditionally connected, whether they survived in oral or printed sources. This body of songs, therefore, falls under the category labelled authentic. The remaining corpus of hymns (by far in the majority) is more easily and clearly defined within the two categories of NEWLYCOMPOSED hymns and EDITORIAL WEDDINGS of texts and tunes. The latter were carried out by various hymnal editors, and the tunes selected usually had secular associations.

\section{IRISH RELIGIOUS SONG IN THE, EIGHTEENTH / NINETEENTH CENTURY}

Both the religious and secular song traditions relied upon oral transmission to a somewhat greater extent when it came to the music associated with these song forms. Two Munster religious poets of this time-Tadhg Gaelach "Súilleabháin (1750-99) and Pádraig Denn (1756-1828) have been chosen for the purposes of analysing the tune titles of both their secular and religious poerns. The purpose of this analysis is threefold: firstly, to establish any pattern in tune selection which may have existed in the mind of the poet; secondly, to investigate the origins of the tunes which were set to the poems; and finally, to find the earliest reference to these tunes which occurs in printed collections.

As in the case of the secular eighteenth/nineteenth-century poet, these poems sacred and secular-were recorded in the MSS while the tunes selected were popular folk tunes of the time. Many of these folk tunes were used over and over again with varying sets of texts, and - in the case of Tadhg Gaelach's poems - one poem may appear with more than one tune title in the MSS. For example, Eisteach gach eolach san Eoruip go hÉachtach bears two tune references - The Flowers of Edinburgh and Cois leasa a mé go huaigneach. However, these two tune titles refer to the one tune; Cois leasa replacing the former Flowers in a later MS. It would appear that many Scottish tunes and songs -such as The Flowers of Edinburgh-were prevalent in eighteenth-century Ireland since many Scottish titles recur in the tune references: The Lass of Aberdeen, The Gates of Edinburgh, The White Cockade and Charlie Come over the Water are examples. In the case of this latter, Grattan Flood states that «it was a Scotch adaptation of the Irish tune Seaghan Buidhe».

\section{The Tune References of the Sacred and Secular Poetry}

In the case of Pádraig Denn, the eleven poems published by "Foghlú are religious in subject matter. Of the eleven, five contain tune references. Four of these were included in the publication and one appeared in the Tórna MSS.

There are some fifty-nine poems ascribed to Tadhg Gaclach and of these thirty-one are sacred. A table outlining the tune references of both is as follows:

Total

\section{Sacred Poems}

With tune references

Without tune references
31

14

17
Secular Poems

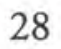

7

21 
Although the sacred poems have twice as many tunes references as the secular, there is no significance in this from the point of view of tune type selection. On an analysis of the tune titles which underlie the sacred poems as opposed to the secular, no pattern of selection emerges.

Three tune references from both poets indicate a religious connection trmbac na Cruinne, Déithe na Cruinne, and Aonmhac na hOighe (Carolan's Devotion apparently refers to a woman whom Carolan admired called Miss Fetherston). There are no tunes in the collections bearing these titles. Two poems, however, which were sung to these tunes have survived within the tradition closely associated with the tune, Seán "Duibhir a' ghleanna -a tune which appears sixteen times in various collections from the eighteenth century. These poems are the Tadhg Gaelach A Óosa Mhic Mhuire, a Righ Ghil na Righthe and Aréir is mé ag machnamh ar Óosa mac m'Athar by Pádraig Denn. In Tadhg Gaelach's tune references, Seán "Duibhir appears consistently, along with rmbac na Cruinne and Déithe na Cruinne. In Denn's case, the only tune reference mentioned is Aonmhac na hOighe. The tune however, to which this poem appears in the printed sources, is clearly a variant of the popular air of Seán "Duibhir a' ghleanna. Furthermore, this song is sung by the traditional An Rinn singer, Nioclás Tóibin, again to a version of this air A ...osa Mhic Mhuire or Duan Criost also was published by Ni Annagáin in 192718 and here she states unambiguously: "This air, which resembles Sean "Duibhir an ghleanna has never been sung to any words but these".

Ni Annagáin was very much a pioneer in preserving and documenting the majority of these poets' hymns, not only publishing them herself in Londubh an Chairn in 1927 but also contributing many of them to other editors. She was obviously aware of the tune references to these poems and it would appear that she wedded the original airs to some of these poems, for example, Mo Ghrá-sa mo Dhia and Gile mo chroidhe do chroidh-si a Shlánaightheoir. Her note on the latter clearly indicates this: "The air to which it is set is Sa Mhainistir Lá (In Fermoy one day), ... I give this air here as it was sung by my father...» This analysis led to the following conclusions:

1) No significant pattern of tune selection was employed by the poets when setting their religious verses to a tune.

2) Where more than one tune reference appear in the MSS, and where some of these tune titles do not occur in the collections, it is likely that these tune titles are titles of poems previously sung to a traceable tune.

3) All the tune references dealt with here would appear to have been popular folk tunes of the eighteenth century-obviously much more accessible to the poets than the printed collections.

4) Pádraig Denn's choice of tune references shows a strong Tadhg Gaelach influence since three of the five Denn titles also appear in Tadhg Gaelach's work. Aonmhac na h"ighe is possibly a poem title referring, to the air of Seán "Duibhir a' ghleanna.

5) A limited number of these religious songs is known and currently sung today for two reasons: firstly, many hymnals and collections have included these songs and secondly, a fraction of these poems have been transmitted orally and have survived in the repertoire of some seun-nós singers.

\section{THE PRINTED SOURCES (1877-1992)}

The material in printed sources falls into two categories: that which consists of music only; and that which consists of music and words. Having assembled this repertoire, the three broad categories of religious songs-authentic, editorial wedding and newly-composed-apply.

\section{The Authentic Song in the Printed Sources}

Although the printed sources form the greatest corpus of religious material, only a small percentage of these can be termed authentic. Of the four textless collections, the Hoffman Petrie and Stanford Petrie provide invaluable authentic material particularly because they represent the first printing of some of the oldest pieces of religious song. 
The most far-reaching results in compiling and spreading religious song were obtained by lay editors. Máiréad Ni Annagáin and Séamus Clandillon laid the foundation of a vernacular hymnology as early as 1904 when they contributed three hymns to An tSollamhain Dhiaganta Eireannach (The Irish Religious Celebration) in London, published in 1906. These hymns formed a viable replacement of Dánta Dé for the choirs and congregations of the sixties and seventies and were based upon the authentic religious music of the Irish people.

Four other publications are relevant here: firstly, in 1973, Ceol published Caoineadh na dTrí Mui$r e$ from the singing of Seosamh "hÉanai. The most important source of songs appeared in Irish Folk Music Studies -eleven pieces collected and notated by Hugh Shields and Angela Partridge from Galway and Donegal; and finally, two articles by Breandán" Madagáin -the first in Béaloideas with a reconstruction of Sciathluireach Mhuire and Laoi Chnoc an Air and the second article of interest in the area of religious song generally, printed in An Sagart entitled Ambrain Bheannaithe: An Traidisiun Dúchais.

\section{Editorial Weddings of Tunes and Texts in the Printed Sources}

The bulk of religious material published belongs to this category. The tunes selected fall into three subdivisions: tunes from previous collections of Irish folk music; tunes of hymns in languages other than Irish; and tunes from other sources.

Within these subdivisions, tunes from previous collections are tunes with or without religious association. The earliest examples of a tune selection with a previous religious connection appears in $A n$ tSollamhain Dhiaganta Eireannach. Although not clearly stated, it would appear from other pieces in this collection that Ni Annagáinl Clandillon contributed Beannacht leat a Mhuire, a poem originally collected by Dúbhglas de hÔde. The tune selected first appeared in the Hoffman edition of the Petrie MSS ' in 1877 under the title of chant. The Stanford edition expands the title to Chant or Hymn tune, Co. Donegal from Revd. James Mease, Freshford. In Dánta Dé, the editor sets a variation of the tune to four different texts including Beannacht leat, and one text is an Irish translation of Sancti Venite. In stating the tune source there is a slight variation of dates. In the case of two settings, the sources are stated as «ó ms 1756 tré. G. Flood, Dr. Mus.», one setting of the tune is unacknowledged and the final setting bears the note "Sean-cheol Gaedhealach "MS. 1750" G. Flood dr. cheoil» The tune is entitled Sancte Bhenite, which as a text has extremely old Irish connections. As already stated in the introduction, it first appears in the seventh-century Antiphonary of Bangor and although we know that it was a very popular eucharistic hymn in medieval Ireland, there is no evidence to suggest the musi$\mathrm{cal}$ nature of the original tune to which it was sung. Grattan Flood's manuscript studies possibly led him to connect this tune with Sancti Venite and Ni "gáin implies this in her introductory acknowledgements: «agus do'n Dochtúir L. Grattan-Flood, do chuir chugam sean-cheol an Sancte Bhenite...".

The number of texts set to tunes with no religious connection is much greater, perhaps because many of the poems are in ambrán metre and are easily wedded to secular folk tunes. Although not the earliest example, a typical construction of this kind is Mile baodhchas lead-sa, a Fhir-Spioraid naombt$h a$, an early nineteenth-century poem by Uilliam "Marnáin. Here, it is wedded to the traditional version of Sliabh na mBan which was contributed by Séamus Clandillon, one of/na Ni "gáin's many informants and sources. Furthermore, the categorisation of editorial weddings also contains pieces where the original tune is retained and set to an Irish translation of a hymn-the earliest example being an Irish language version of Adeste Fideles in 1916. Two collections employ this editorial device to a very large extent Leabhar Iomann (1961) and Duanra (1975), where in both cases, the purpose of these collections was to provide a functional Irish-language hymnal for church use for both the Church of Ireland and Catholic church communities respectively.

Finally, many Gregorian chant melodies were deemed desirable by editors for settings where, apart 
from direct translations of the Latin text to Irish as in the categorisation discussed above, an Irish (tuneless) text is adapted to the chant. A popular hymn sung in Roman Catholic worship today is Gabhaim Molta Brighde, wedded to the simple Gregorian chant Ave Maris Stella, presumably by An tAthair Pádraig Breathnach who first published it in 1916.

\section{Specially or Newly-Composed Tunes in the Printed Collections}

No distinction is made here between entire hymns (both words and music) being composed by the one person, and newly-composed tunes for a pre-existing text. Defining, identifying and labelling this category of religious song is by its very nature far less fallible and problematic in collections up to the 1960's. In some later collections, however, such as An Choisir Cheoil and the Veritas Hymnal many new compositions are erroneously entitled traidisiunta or traditional. These classifications can be misleading especially in terms of observations such as the following:

But it is tempting to hear traces of Gregorian chant in many Irish Gaelic religious tunes, as for example in Is maith an bhean Mhuire Mhór, Gabhaim Molta Bride, Seacht Subhailci na Maighdine Muire, An Bhainis Pósta i gCána and even Deus Meus Adiuva me. There is no question of the words of these songs being old, but the music could very well be our oldest folk music.

An Choisir Cheoil is obviously the printed source of reference for the songs quoted above and of the five hymns mentioned, two are newly composed, one is a previous editorial wedding and two are authentic folk hymns.

It is the nature and source of these two hymns -Seacht Suáilci na, Maighdine Muire and An Bhainis Posta igCána -as these survive in the oral tradition which allows them to be advanced as «very well... our oldest folk music».

\section{The Ossianic Ballad Connection}

The earliest collection containing any religious material is the Hoffman edition of Petrie in 1877. Here, one of the pieces bears the title Hymn (from Ossian's Poems). However, it appears to bear little or no relationship to the two remnants of Ossianic Ballad which are recorded in the department of Irish Folklore.

Some twenty years later, the Stanford edition of Petrie appeared with fifteen textless tunes where the titles indicate a religious connection. Professor Breandán "Madagáin has restored an Ossianic ballad and a Marian religious traditional text to one of these tunes which actually appears twice in this collection. In the collection containing words and music, the earliest authentic piece appears in Cláirseach na $n$ Gaedhal entitled An Bhainis Pósta bhi i gCána. The suggestion under the title here that this tune is taken from Gregorian chant is obviously an editorial comment although it is interesting to note the following description of the original airs to which Ossianic balladry was sung:

Ossianic ballads were originally sung to simple airs with a wandering rhythm, reminiscent of plainchant and suited to the rhythms of their syllabic metre. These- comparatively free rhythms -differ greatly from the fixed rhythms of present day song-rnetres...

A variant of this fragment has survived with an Ossianic laoi entitled Laoi na Mná Móire. /na Ni "gáin contributed this tune to The Gaelic Churchman in 1920 which she set to an Irish language translation of Te lucis ante terminum. In a note accompanying this setting she stated the source of her tune as Antoine "Dochartaigh. Ni "gáin further stated that the text and tune printed in Cláirseach na nGaedhal comprised a fragment of a longer narration: «The tune is an ancient narrative folk-chant, given me by ... Antoine " Dochartaigh, 0.S., Falcarragh, who learned it from his mother, who died at Harp Island, Donegal, at a great age. She sang it to a long versified History of the Incarnation and Life Christ, in Irish. A fragment of this (the Marriage at Cana) has been published by the Gaelic League."

The second remnant of Ossianic balladry on archive tape -Laoi na bhFian- sung by Micheál " hfgh- 
ne in 1946, is similar in structure and melodic outline to a Petrie tune. This tune is entitled Ancient bymn to be sung in Country Chapels. The final phrase in both tunes is identical. An irregularity of phrase length is also consistent in the two pieces, in which the third and fourth phrases are shorter than phrases one and two.

\section{The MSS Sources of Traditional Religious Song}

Two pieces in MS form were both collected in Donegal by Máiréad Ni Ghiobúin in March of 1934. D'érigh na Trí Mhuire is a textual variant of Gul na dTri Muire published in Ant-Ultach in 1928 and there are many sets of words for this song recorded in the Department of Irish Folklore at University College, Dublin. The musical form of this piece follows the numerical carol/amhrán pattern where the chorus is an exact repetition of the verse. In this case also, the verse in itself consists of two phrases- $A B$-repeated-AB.

The second MS piece is entitled Na Seacht Subhailce. Since it falls into three sections, it seems to be a close variant of the Maggie Antoin carol although all versions of this Donegal numerical carol are very similar particularly with regard to the second phrases which are practically identical. A version of this carol was published again in An Lóchrann collected from Nóra Dhonnchaidh Bhaoighill from Rann na Feirsde. This published variant of the tune differs from the MS version by being cast in a major key.

Although no specific source is mentioned by Máiréad Ni Ghiobúin for the two above songs, there is no doubt that they were not collected from traditional folk sources; they fall therefore into the Authentic religious song category.

\section{ORAL SOURCES OF TRADITIONAL RELIGIOUS SONG IN IRISH}

Archive collections (both private and institutional), tape recordings and commercial recordings yielded some eighteen pieces of importance, and these along with the printed and MSS authentic songs will be defined and grouped under three broad categories of tune types.

\section{The Ambrán-Type}

As the term is used in this context, the amhrán-type of religious song refers to that form of stressmetre song of which most examples date from the seventeenth century onwards. The poet is known in the case of five of the seven songs. Furthermore, seven of the nine different tunes to which these poems were set were not composed for the religious text but were pre-existing folk songs of the time. Three other features of this tune type are firstly, the absence of a chorus or refrain in all cases, secondly, a four-phrase structure in each tune and finally, in all but one, a ternary musical form.

The reappearance of the tune-title Sean "Duibhir a' ghleanna occurs in hymns from both the oral and printed sources, and five of the thirteen poems here bear this tune. Given the many secular texts set to this tune, and the following affinnation of its popularity by Patrick Weston Joyce, it seems unlikely that its recurrence is deliberate or intentional, or that as a tune type it bore any special religious significance for poets: "Of all the songs that prevailed among the Munster people of the last generation, not one was so great a favourite as this» [John O'Dwyer of the Glen.]

\section{The Numerical Carol}

The term carol needs careful clarification. Much ambiguity and confusion arise from the carol literature in England on two issues. The carol as it appears in MS form bears no relationship with the folk carol except in the presence of a refrain. Eric Routley clearly states that the medieval MS carol is the precursor of the folk song carol, and that the former «went underground in days of Puritanism. The dance form in which it (the MS carol) was cast became meaningless with the decline of the processional dance». 
The first documentation of both of these carol types illustrates the vast distance, not only historically but also in transmission, that exists between them. Few musical examples of the early medieval carol are extant. Many of these are polyphonic and far removed from the folk art creation of these islands. The music of the folk carol, on the other hand, was first documented and published in 1833.

The second issue concerns the subject matter of the carols. Professor R. Robbins names six functions of the carols: a profane song associated with dancing and revelry... a formal dance song ... a convivial song (religious or profane) for public singing ... a ceremonial song ... a pious song," not associated with dancing and pageantry... a professional hymn.

The following definition, however, would appear to be the one most suited to the carols which have survived in Ireland:

The carol stands midway between the hymn and the ballad and may be regarded with equal propriety as a secular hymn or a sacred ballad.

The Seven Joys of Mary as it survived in the English folk tradition has been labelled a numerical carol, the numbers being a mnemonic aid to the various religious mysteries and events.

The most striking feature of the numerical carol in Ireland is the presence of a chorus in all cases except two and, furthermore, the structure of the chorus follows a unique pattern of being a direct repetition of the music of the verse. Thus, each numerical carol revolves around two distinct musical phrases (A and B) with sometimes up to five variations of these.

Six of the nine numerical carols were collected in Donegal -five being versions of Seacht Subháilci na Maighdine Muire. The Seacht nDólás carol -although slightly suspect and imperfect- is nonetheless a musical variant of the five other Donegal carols. In addition, since this Dólás carol is the same tune as the suailci carol of this informant, it raises the point as to whether these texts and tunes were interchangeable. A further interesting musical connection has been made between this Donegal Dólás numerical carol and the British ballad, Little Sir Hugh.

The Munster version of Seacht nDólás is a very different lyrical tune and was collected in Uibh Ráthach and Baile an Fhirtéirigh, Co. Kerry. An tAthair Diarmuid "Laoghaire recalls the performance context of this carol as he experienced it.

Chuala féin go minic i gCiarrai Seacht nDólás na Maighdine Muire á rá ag seanbhean tar éis an Phaidrín agus ba bhreá leat bheith ag éisteacht léi agus an crónán a chuireadh si leis agus an diograis ina guth.

[I myself often heard an old woman in Kerry singing 'The Seven Sorrows of Mary' after the Rosary, and you would love to he listening to her and the humming she would put into it and the fervour of her voice.]

This carol falls into two musical categories, the chorus being an almost identical repetition, as in the case of the Donegal numerical carol.

The text of this chorus, however, centres on aililiu as opposed to the more predictable doleful ochón of the Donegal and Connemara versions.

The Ní Ghuairim version is perhaps the most intricate, ornate version although it still adheres to two phrases, both repeated as a chorus. The two-phrase tune here is also that used by the same singer for the religious ballad Caoine na dTri Muire. This interchange of text and tune already occurred within the Donegal remnants but the fact that each time this interchange was recorded by the same singer is perhaps significant.

A study of the texts of both the joys and sorrows at large is outside the scope of this article, yet certain observations of the Connemara and Kerry choruses reveal some important features. Although the mother and child dialogue inherent in these two choruses does not appear to have been an integral part of the English numerical carol, it certainly seems to have been a feature of some carols: 
The English carol with its tender compassion for the sufferings of mother and child was a product of that chivalry that had been brought to this country in the eleventh century by the courtly love poets of Southern France. It seems reasonable to conclude that the English carol originates... in the chivalry of the troubadours which fashioned its speech, and gave it its character.

In his discussion of secular and sacred Irish songs with chorus, Seáin "Tuama has shown that many of the refrains of the simple Irish songs are similar to those which were danced to as carols in Europe.

Ní thuigim, áfach, gur chóir puinn amhrais a bheith ann ná gur fhás cuid mhór d'amhráin luinneogacha na Gaeilge ar an nós céanna ar fhásadar ar fud na hEorpa i.e. trí iad a bheith ceangailte le rince cruinn nó ar a laghad, tri iad a bheith bunaithe ar cheol na rinci sin.

[I do not think, however, that there is any doubt that most of the Irish language songs with a chorus evolved in the same way as in Europe, i.e. through their association with round dances or, at least through their being based on the music of these dances.]

Various theories exist about the antiquity of the English numerical carol although it is unanimously believed to date to pre-Reformation times. Number symbolism in the medieval mind was: believed to have been of God's own implanting... By symbolism, the abstract beauty and loving-kindness of the Deity were humanly realised in the person of the Virgin.

V.F. Hopper further suggests that Babylonian number philosophy, wherein the number seven appears in many tablets, was adopted by the Christian church and paved the way for «the regular calendar with saints' days, lunar cycles, the seven dolors of the Blessed Virgin Mary, the trees of vices of sinners, showing the branches of the seven deadly sins, the seven petitions of the Lord's Prayer..."

Since the association of the number seven with the Christian church seems so strong, Eric Routley surmises that this type of numerical carol was used as an instrument for spreading the basic doctrines of faith. The cumulative nature of building doctrines on numbers would have served as a mnemonic aid to the instructed. He also connects the carol movement with St Francis of Assisi: this view is further developed by Douglas Brice who states that with the arrival of the Franciscans in England in 1224, the vernacular carol was used as an effective means of instructing the people. Since the Franciscans arrived in Ireland two years later in 1226, it is likely that this form of the carol was introduced in Ireland at that time.

\section{The Religious Ballad}

The term ballad has been defined and redefined many times in relation to the carol in the English folk music tradition and there is an overlap between both in many respects. The following definition is the most accurate to describe this traditional Irish religious song-type:

A strophic folk-song with a strong narrative element... normally without melodic repetition within a stanza.

The texts of these songs certainly narrate a story largely centred on the Passion story in one form or another. The one apparent exception here is An Bhainis Pósta bhi i gCána. This as we have seen, is a fragment of a long versification of the History of the Incarnation and Life of Christ. The music in these religious ballads is generally subservient to the story and very often comprises but two different phrases, both of which are sometimes repeated as a chorus.

A religious ballad is therefore a narrative which may or may not contain a chorus. The text is strongly Marian-centred, a feature which it shares with the numerical carol the overlap here heightened further by the appearance of the one tune for a piece from both categories. The religious ballad type contains nineteen pieces, as opposed to nine numerical carols and thirteen amhrán types. Leaving aside the tune structures, it is interesting to note that the amhrán-type religious content makes little or no mention of Mary and, furthermore, that the religious content of the eighteenth-century poets 
surveyed also excludes Marian devotion. The poets in the large majority of amhrán-type songs are male. There may indeed be reason to suggest that many of the Marian-centred numerical carols and religious ballads may have been authored by women. A brief observation of the broad nature of the relevant texts clearly indicates a distinct style and bias. The hymns of Mary stem from a personalised identification with her at the foot of the Cross as mother first and foremost, and ultimately as keening woman. Even the very titles and variety of the word Caoineadh indicate this connection.

Both of the above claims can also be musically substantiated. When one looks at the construction of many of the women's secular songs, a definite pattern of distinct different phrases emerges. Similarly, the caoineadh pattern corresponds with the basic ballad definition above. Secondly, the music of the pre-Christian caoineadh, is not only through-composed but displays a very deliberate form-each phrase beginning with the highest note and always coming to rest on the same note. This unique feature of phrase-ending is also to be found in a lullaby transmitted by Sorcha Ní Ghuairim (who was a very important source of traditional religious song). Such a feature may suggest both female creativity and antiquity.

\section{Religious Music and the Seventeenth / Eighteenth-Century Harpers}

There is no evidence in any of the printed sources, or indeed within the living tradition, to suggest that traditional musicians, with the sole exception of the harper, included pieces of a religious nature in their repertoire. One of the earliest references to the participation of the harper in religious music is found in a poem written by Cathaoir MacCába to his contemporary Turlough " Carolan, the eighteenth-century harper.

Cogadh is cathughadh ar feadh na rioghachta

Atá ag éisteach

Le cantarum gliarum glearum

Ar gach féasta,

\section{[There is dissension and trouble throughout this kingdom}

Which has to listen

To your "cantarum gliarum glearum"

On every feast-day.]

It would appear that several harpers may have, on occasion, played together during the Mass: «Denis O'Connor... hired a number of harpers to Strike up a solemn concert at Midnight Mass (for it was Christmas Eve)...».

There are two direct references to Carolan himself playing at Mass. One states that Carolan frequently assisted with his voice and his harp at the Elevation of the Host and had composed several pieces of church music which were deemed excellent.

The second is a quotation from Charles O'Connor:

On Easter Day I heard him play at Mass. He played the piece Gloria in Excelsis Deo, and he sang that hymn in Irish verses as he played. At the Lord's prayer he stopped; and after the priest ended he sang again and played a piece which he nominated The Resurrection. His enthusiasm of devotion affected the whole congregation.

Of the three pieces mentioned here-Gloria in excelsis Deo, The Resurrection and The Elevation only the last is documented. This is published in Lee's Favourite Collection 74 and seems to be an attempt by Carolan to imitate a type of organ piece called The Elevation Toccata which was in vogue during his time. The organ piece frequently falls into two sections, the first being in free improvisatory form and the second metrical and fugal in character. This structure is to be seen clearly in Caro- 
lan's Elevation where the piece moves from a free common time into a regular three-four metre. Obviously only the basic melody has been noted and it is not known what type of bass was used, if any. Nonetheless, this is another instance of the commonly accepted influence of Italian Baroque music on Carolan's style.

Finally, The Memoirs of Arthur O'Neill contain a reference to the eighteenth-century harper, Thady Elliott, playing at a Roman Catholic Mass in Navan. Much of the atmosphere of the harpers' contribution to the liturgy comes across in this account:

On a Christmas Day, Thady was to play at the Roman Catholic Chapel of Navan, and a humorous fellow in Navan took Thady to a public house and promised to give him a gallon of whiskey if he rattled up Planxty Connor at the time of the Elevation, which Thady promised to do. Accordingly, when Mass commenced on Christmas morning, Thady as usual played some sacred airs until the Elevation, and for the sake of the whiskey and [to] be as good as his word he lilted up Planxty O'Connor. The priest who was a good judge of music, knew the tune but at that solemn stage of the ceremony he could not speak to Thady. But to show his disapprobation he stamped violently on the altar -so much so that the people exclaimed in Irish, "Dar Dhia, tá an sagart a' damhsal!» that is "By God, the priest is dancing!». However, after playing Planxty Connor for some short time, he resumed his usual tones. But when Mass was over Thady was severely reproved and dismissed.

\section{CONCLUSIONS}

It has generally and mistakenly been held that Ireland possessed little or no traditional religious music. Certainly, no form of hymnology evolved in Ireland (not even in the English language) and the reasons for this are inextricably bound to the social history of the people.

Over two hundred religious songs, however, - texts and tunes - appeared in printed sources from 1877 to 1992 , and in addition to these, eighteen tunes can be included where the title indicates a religious connection. I have classified all of these under three categories: Editorial weddings of text and tune; Newly-composed songs; and the most important category, Authentic songs where words and music are obviously traditionally connected and, in most cases, collected from the one source. There are over forty Authentic pieces in all including the textless tunes. Furthermore, these songs can now be added to the songs and pieces which emerged from tape archive, commercial recording, MSS sources and the live tradition which by the very nature of their transmission were automatically labelled as Authentic.

The song-types are evident within this Authentic repertoire -Amhrán-type, numerical carol and religious ballad. In the amhrán-type, the composer of the poem is known for the most part, and seven of the tunes to which these poems are set are popular song-airs of the eighteenth century. The absence of a chorus in all of these songs is significant but the most important feature here is that these poems (and, to a lesser extent, tunes) can be generally dated and have a very different structure and form from the musical structure of the other song-types. The numerical carol and the religious ballad have many similarities, and indeed could be collectively entitled Ceol Reacaireachta, a term used by Professor Breandán "Madagáin to categorise the music of the caoineadh, the laoi Fhianaiochta, and the syllabic hymn among others.

The first striking similarity between the carol and the ballad is the subject matter of all these songs, which centres on Mary while the amhrán-type does not. Secondly, the vast majority of both ballads and carols contain choruses which often are musical repetitions of the verse, and the phrase structure rarely exceeds two phrases. The ballad is synonymous with story-telling, and thus the fourteen songs here narrate various stories-sometimes the dialogue between Mary and Christ on the cross, sometimes the Passion Story, and in one case (itself a fragment of a longer narration of the life of Christ) the Wed- 
ding feast at Cana. In England, the Numerical carol is widely held to have been introduced by the Franciscans in the thirteenth century. Although there are no apparent similarities between the Irisł and English versions, it nonetheless is possible that this song-form was introduces to Ireland at the same time, and that popular tunes were wedded to sacred texts. These texts were for the most part sim. ple and repetitious for the purpose (presumably) of spreading doctrines of faith.

Certain connections, not only between traditional religious songs themselves but between the religious song tune and other song forms, are probable. The most striking of these is the interaction between Ossianic ballad melodies and religious tunes. Furthermore, some secular women's songs display a similar musical structure to many of the oldest religious tunes. Therefore, these songs could perhaps have been written by women. The fact that many of these texts identify with Mary as mother and keening woman would seem to indicate a strong female influence.

From various references, it is obvious that the seventeenth/eighteenth century harper involved himself with religious music. It would appear that this involvement was not confined to instrumental playing, since there are references to Carolan singing two hymns in Irish to his own accompaniment at Mass.

The findings of a study of the tune references appended to the religious texts of two eighteenthcentury poets are given in Appendix 1, which shows that many of these poems appear in the collections wedded to tunes other than those designated by the poets, and that four others have been transmitted orally with the original appended tune. Finally, in seeking to create a viable native hymnology, editors have failed for many different reasons to take the Authentic traditional religious song into account. The technique adopted by such editors has been to select, in most cases, highly stylised poems and to set them to sometimes unsuited tunes or, to tunes which had no previous religious connection. However, the success or failure of this music within church worship is peripheral here -as indeed is the question of male or female authorship. The most important aspect of this study is that the tunes of the Authentic religious song in Irish are among the oldest traditional music to have survived to the present day. 


\section{RESUM - ABSTRACT}

Natura i classificació de cançons religioses tradicionals irlandeses amb un repàs a les fonts impreses $i$ orals.

S'ha sostingut erròniament que Irlanda no comptava amb música religiosa tradicional. És cert, però, que no va existir una evolució himnogràfica. Una de les poques fonts dels cants religiosos tradicionals irlandesos es troba a les vides dels Sants. No és facil estudiar la natura dels cants amb tant pocs vestigis, però es pot dir que el cant religiós era una part important de la vida monàstica. En aquesta època, el tipus de cant en ús era una forma de cant Gaèlic que al segle XII, va ser substituït pel cant romà, més ornat $\mathrm{i}$ complicat.

S'han classificat al voltant de 200 cants religiosos (textos i melodies) en tres categories: unificacions de text i melodia, cançons de nova composició $i$, les que més ens interessen, cançons autèntiques amb lletra i música tradicionals. $\mathrm{Hi}$ ha al voltant de quaranta peces autèntiques, incloses les melodies sense text. Dins d'aquesta última categoria, hi ha tres tipus de cançó: la cançó de tipus Amhrán, la nadala numèrica i la balada religiosa. Aquests tres tipus són estudiats, especificats i comparats.
It has generally and mistakenly held that Ireland possessed little or no traditional religious music. It is true, though, that no form of hymnology evolved in Ireland. The lives of the saints convey the scanty details on early Irish chant. It is difficult to discuss the precise musical nature of the chant but it may be said that church chant was an integral part of monastic life. At this time the type of chant in use would appear to have been a form of Gallican chant which gave way to the more ornate, intricate roman chant in the twelfth century.

Over 200 religious songs -texts and tunes- have been classified in three categories: editorial weddings of text and tune, newly-composed songs and, the most important category, authentic songs with traditionally connected words and music. There are over forty authentic pieces in all including the textless tunes. This last category includes three kinds of song: the Amhrán-type, the numerical carol and the religious ballad. These three types are studied, specified and compared. 